\title{
ELECTROMYOGRAPIC ACTIVITY OF THE ABDOMINAL AND PARAVERTEBRAL MUSCLES DURING COFFEE HARVESTING
}

\author{
ATIVIDADE ELETROMIOGRÁFICA DOS MÚSCULOS ABDOMINAL EPARAVERTEBRAL DURANTE \\ A COLHEITA DECAFÉ \\ ACTIVIDAD ELECTROMIOGRÁFICA DE LOS MÚSCULOS ABDOMINAL Y PARAVERTEBRAL DURANTE \\ LA COSECHADECAFÉ
}

\begin{abstract}
Edmar de Lima' (ID
(Graduate Student of Physical Education)

Thiago Oliveira Santos ${ }^{1}$ (ID (Graduate Student of Physical Education)

Wonder Passoni Higino 1,2 (D) (Physical Education Professional) Renato Aparecido de Souza ${ }^{1,2}$ (ID (Physiotherapist)

Fabiano Fernandes da Silva' (ID) (Physical Education Professional)

1. Instituto Federal de Educação, Ciência e Tecnologia do Sul de Minas Gerais (IFSULDEMINAS), Campus Muzambinho, Muzambinho MG, Brazil. 2. Universidade Federal de Alfenas (UNIFAL-MG), Postgraduate Program in Rehabilitation Sciences, Alfenas, MG, Brazil.

\section{Correspondence:}

Edmar de Lima.

Rua Francisco Lauro Guimarães, 51, Jardim Ceravalo, Muzambinho, MG, Brazil. 37890-000.

edmarlima2015@hotmail.com.
\end{abstract}

\begin{abstract}
Introduction: The rural worker involved in the coffee harvest is an important person for the economy of the many countries. However, scientific studies on the health of this worker are rare. Objective:To analyze the lumbar paravertebral musculature and abdominal rectus of rural workers during coffee harvesting with the manual machines with different footrest bases (inclined, declined and horizontal), by means of electromyography. Methods: Eight male rural workers from the region of Muzambinho participated in the study. All procedures and electromyographic routines were applied according to the SENIAN protocol. The workers made the usual coffee harvesting movements, using the manual machine for one minute. The data are expressed as means and standard deviations. The RMS (root mean square) signal and the median frequency (FM) were also analyzed. Results: It was observed that the type of footrest base did not influence the electromyographic activity RMS or the FM, but we found that the paravertebral muscles have greater electromyographic activation when compared to the abdominal muscles, regardless of the type of footrest base. Conclusion: For the task performed, the paravertebral muscles present greater electromyographic activation compared to the abdominal rectus. Level of Evidence III; Diagnostic studies - Investigating a diagnostic test.
\end{abstract}

Keywords: Ergonomics; Rural health; Electromyography; Low back pain.

\section{RESUMO}

Introdução: O trabalhador rural envolvido na colheita de caféé um personagem importante para a economia de muitos países. Contudo, são raros os estudos que envolvam a saúde desse trabalhador. Objetivo: Analisar através da eletromiografia a musculatura paravertebral lombar e reto abdominal dos trabal hadores rurais durante a colheita de café com a derriçadeira manual, em diferentes bases de apoio para os pés (inclinado, declinado e horizontal). Métodos: Participaram do estudo oito trabalhadores rurais da região de Muzambinho, do sexo masculino. Todos os procedimentos e rotinas eletromiográficas foram aplicados de acordo com o protocolo de SENIAN. Os trabalhadores realizaram os movimentos usuais da colheita do café utilizando a derriçadeira manual durante um minuto. Os dados foram expressos em média e desvio padrão com o sinal RMS (root mean square), além disso, foi analisada a frequência mediana (FM). Resultados: Observou-se que os planos não influenciaram na atividade eletromiográfica RMS e nem na FM, no entanto, foi constatado que os músculos paravertebrais possuem maiores níveis de ativação eletromiográfica quando comparados aos músculos abdominais, independentemente dos planos. Conclusão: Conclui-se que para a tarefa realizada os músculos paravertebrais apresentam maior ativação eletromiográfica em comparação aos retos abdominais. Nível de evidência III; Estudos diagnósticos-Investigação de exame para diagnósticos.

Descritores: Ergonomia; Saúde do trabalhador rural; Eletromiografia; Dor lombar.

\section{RESUMEN}

Introducción: El trabajador rural involucrado en la cosecha de café es un personaje importante para la economía de muchos países. Sin embargo, son raros los estudios que abarquen la salud de este trabajador. Objetivo: Analizar a través de electromiografía la musculatura paravertebral lumbar y recto abdominal de los trabajadores rurales durante la cosecha de café con la cosechadora manual, en diferentes bases de apoyo para los pies (inclinado, declinado y horizontal). Métodos: Participaron en el estudio ocho trabajadores rurales de la región de Muzambinho, del sexo masculino. Todos los procedimientos y rutinas electromiográficas fueron aplicadas de acuerdo con el protocolo de SENIAN. Los trabajadores realizaron los movimientos usuales de la cosecha de café utilizando una cosechadora manual durante un minuto. Los datos fueron expresados en promedio y desviación estándar con la señal RMS (root mean square) y también fue analizada la frecuencia mediana (FM). Resultados: Se observó que los planos no influenciaron en la actividad electromiográfica RMS y tampoco en la 
FM, sin embargo, fue constatado que los músculos paravertebrales poseen mayores niveles de activación electromiográfica cuando comparados a los músculos abdominales, independientemente de los planos. Conclusión: Se concluye que para la tarea realizada los músculos paravertebrales presentan mayor activación electromiográfica en comparación a los rectos abdominales. Nivel de evidencia III; Estudios diagnósticos-Investigación de

\section{examen para diagnósticos.}

\section{Descriptores: Ergonomía; Salud de la población rural; Electromiografía; Dolor de la región lumbar.}

\section{INTRODUCTION}

Ergonomics is an interdisciplinary science that has as main objective to adapt work environment to the human beings psychophysiological characteristics ${ }^{1}$. Among the applications of this science it has been described the prevention of skeletal muscle disorders, being the low back pain one of the most prevalent situations and of greater impact to the worker ${ }^{2}$.

According to Queiroz, Schettino and Minette ${ }^{3}$, the low back pain is closely related to the professional profile. Professions that require some physical load, associated with improper postures and repetitive movements can cause pain especially in the low back region. This clinical condition is highly prevalent and may affect both genders, with sudden, intense and prolonged pain ${ }^{4}$. According to data from World Health Organization, $80 \%$ of the adult population may suffer from low back pain at some point in their lives ${ }^{5}$, with recurrences rates of $30 \%$ to $60 \%$ are related to the type of work 4

Coffee harvesting requires that the work performed involves several postures and differents weights, which can be potentially harmful to the health of workers involved in these activities ${ }^{6}$. in the literature there are several studies on ergonomic applications in various types of work environments, such as sawmill ${ }^{7}$, eucalyptus seedling production ${ }^{6}$, coffee bag carriers ${ }^{8}$ and also in sports, such as cycling ${ }^{1}$, thus seeking to make adjustments for its improvement. However, researches on ergonomic assessments of workers during coffee harvesting are still rare.

The rural worker involved in coffee harvesting is a very important character for the social and economic context of several regions of Brazil and the world. However, scientific studies involving the health of this workers are rare. A possible line of investigation could be the utilization of validated instruments to observe of the muscle-joint impact during work activities, and a tool that can be used is the electromyography (EMG) ${ }^{9}$.

Understanding how a muscle is required during work activity is important for the identification of muscle overloads and the elaboration of specific strengthening programs ${ }^{1}$. Thus, the aim of this study was to analyze by EMG, the lumbar paravertebral musculature and abdominal rectus muscle of rural workers during coffee harvesting with the use of the manual machine, a usual tool used in this activity, employing different footrest bases (inclined, declinated, and horizontal).

\section{MATERIAL AND METHODS}

A field research was carried out in a cross-sectional experimental format, in which EMG was used as an analysis tool during the action of workers in the coffee harvest. Participated in the study 08 (eight) rural workers from the region of Muzambinho, Minas Gerais, male, with average age $33.25 \pm 18.03$ years, average body mass $74.37 \pm 10.25 \mathrm{~kg}$, average height $176.25 \pm 9.85 \mathrm{~cm}$. All participants had experience with this activity, and had a daily work routine of 8 hours, totaling 40 hours per week. None of the workers had injured muscles. All workers, prior to their participation, were informed and signed the Informed Consent Form (ICF). Prior to the collection procedures, the present study was submitted to the Ethics and Research Committee of the Juiz de Fora Higher Education Center and approved (opinion number 2.280.938).
At the first moment, the electromyographic data of the rectus abdominis and paravertebral muscles were collected during the usual coffee harvesting movements using the manual machine employing three footrest bases (declined, inclined and horizontal), with a collection time of one minute for each plan.

The analysis of the different footrest bases is justified due to the topography of the coffee regions, that is, the different levels of inclination and the economic condition of the producers are factors that directly affect the way the harvest will be done, being mechanized, semi mechanized or manual ${ }^{10}$. Silva ${ }^{11}$ recommends that the land presents a declivity below $15^{\circ}$ for the use of the agricultural harvester. In this way, land with a declive higher than the harvest can only be semi mechanized, for example with the manual machine, or manual. Thus, to standardize the terrain, a $25^{\circ}$ inclined wooden ramp was used to simulate the rough terrain found in the coffee regions.

For the data collection we used a four-channel EMG (Miotec Equipamentos Biomédicos Ltda, Miotool model). All procedures and electromyographic routines were considered according to the SENIAN protocol $^{12}$. The electrodes were fixed over the muscular belly, aiming to reach the rectus abdominis and paravertebral muscles more efficiently. Nine surface electrodes (Meditrace) were used for each person, four for the abdominal muscle and four for the paravertebral and one reference electrode attached to the clavicle. The electrodes were fixed after all the trichotomy procedure and site cleaning to decrease the skin impedance. The positioning of the electrodes was done following the sequence described (Figure 1).

Initially, the pen was used to mark the midpoint between the umbilical scar and the xiphoid process (lower external) that can be located by palpation. The electrodes were positioned laterally three centimeters from the previously established mark between the umbilical scar and the xiphoid process, with two electrodes on each side, also maintaining a distance of three centimeters from center to center of the electrodes ${ }^{13}$

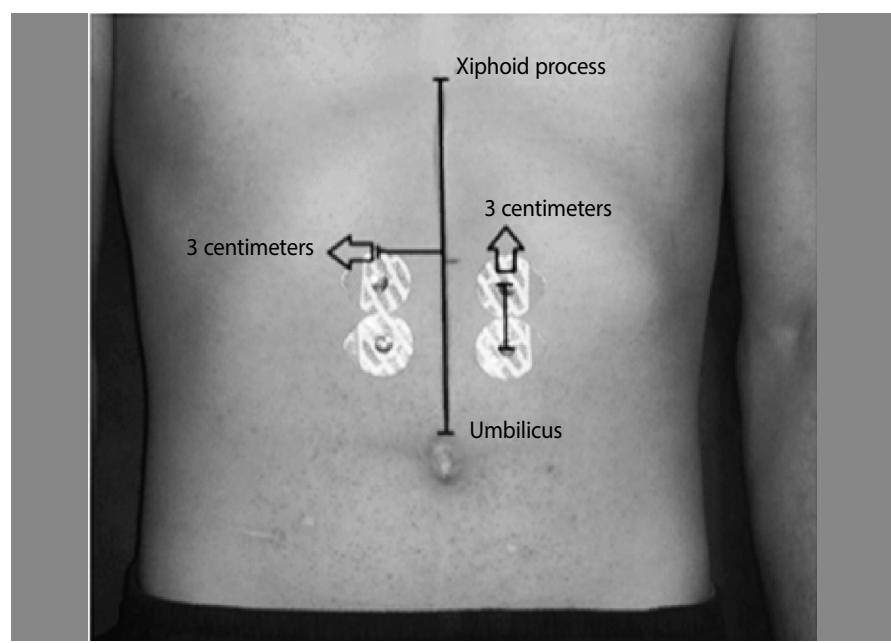

Figure 1. Procedure for placement of electrodes on the right and left rectus abdominis muscles. Image adapted from Silva. ${ }^{13}$ 
The placement of the electrodes in the paravertebral muscles was done after the trichotomy and cleaning procedure to reduce the skin's impedance. Every sequence described was made with the volunteers seated, the muscles were located with reference to a line drawn over the iliac crest. The surface electrodes were placed over the paravertebral muscle region, one on the left and one on the right, at the height of the fourth ( $L 4)$ and fifth (L5) lumbar vertebra, the center of the electrode was positioned respecting a distance of three centimeters from the spinous process from center to center of the electrodes was observed a distance of three centimeters ${ }^{14}$ (Figure 2).

\section{Statistical Analysis}

Data were shown using average and standard deviation. After normality determination by Shapiro Wilk test, a two-way repeated measures (ANOVA; footrest base x muscles) with Tukey post hoc test. For all analyzes, the SPSS version 20.0 statistical package with $p \leq 0,05$. was used.

\section{RESULTS}

It was showed that footrest bases did not influence the RMS (root mean square) electromyographic activity and nor the FM (frequency median). However, it was verified that paravertebral muscles have higher levels of EMG activation when compared with abdominal muscles, independently of footrest bases (Figure 3).

Another important finding concerns the lower fatigability of the paravertebral muscles when compared to the abdominal muscles. Such evidence comes from the lower FM presented by paravertebral than abdominal muscles. (Figure 4).

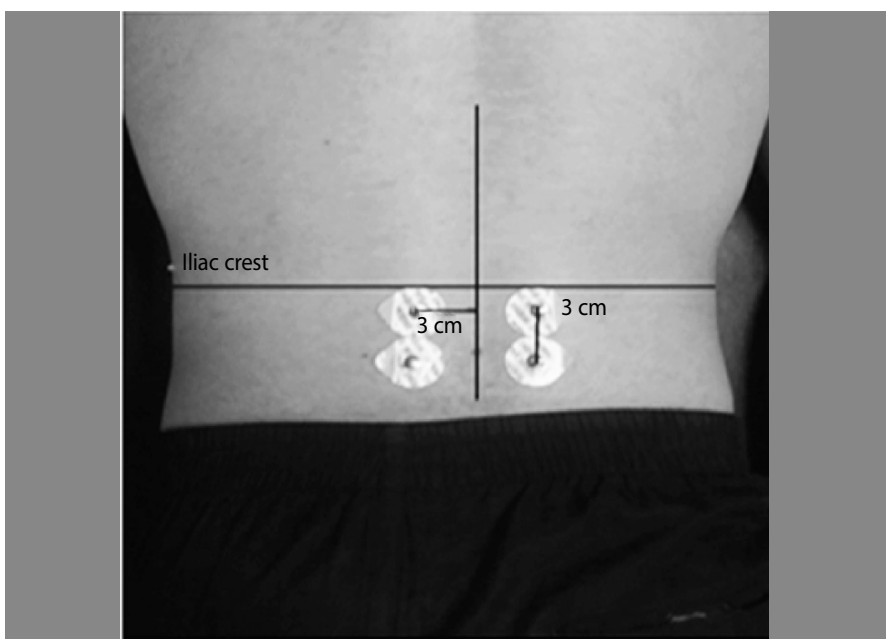

Figure 2. Procedure for placement of electrodes on the right and left paravertebral muscles. ${ }^{14}$

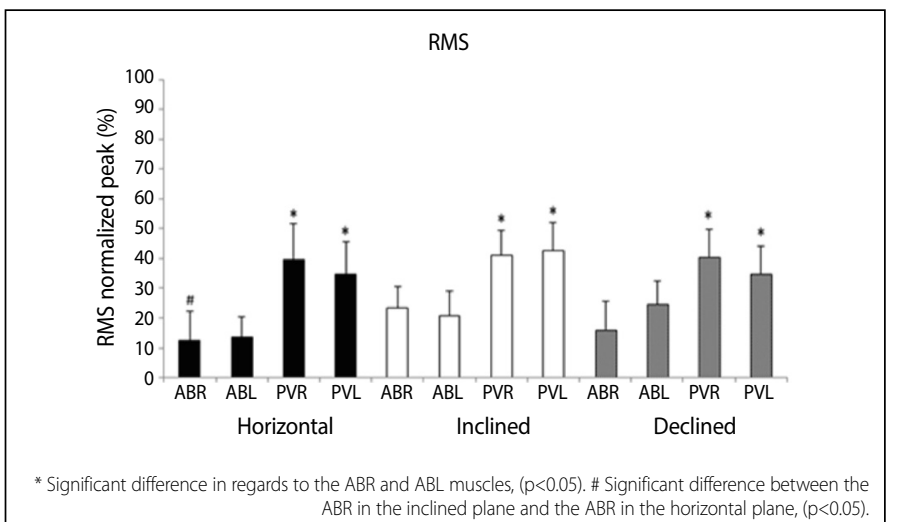

Figure 3. Values in mean and standard deviation of the electromyographic activity (RMS) of the right and left rectus abdominis ( $A B R$ and $A B L$ ) and right and left paravertebral (PVR and PVL) muscles in the different anatomical planes.

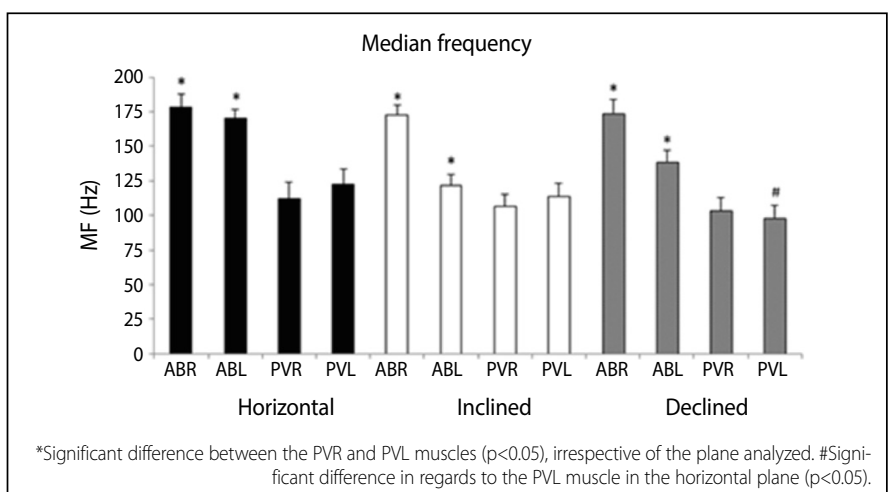

Figure 4. Values in mean and standard deviation of the median frequency (MF) of the right and left rectus abdominis ( $A B R$ and $A B L$ ) and right and left paravertebral (PVR and PVL) muscles in the different anatomical planes.

\section{DISCUSSION}

The main findings of this study are related to a higher electromyographic activation of paravertebral activation when compared to abdominal muscle, independently of footrest bases adopted by rural workers during coffee harvest. Also, it was showed a behavior of FM signal independent of types of footrest bases, associated with higher FMs to abdominal muscles than paravertebral muscles.

As Brazil is one of the world's main coffee producers and, as a result, coffee cultivation is an important catalyst for the national economy, it is essential to carry out complementary research to the isolated prism of coffee beans and coffe quality that also deepen the understanding of the biomechanical aspects of the responsible subjects by harvesting coffee when working.

Tereso et al. ${ }^{15}$ assessed the work physical load in coffee plantation workers compared the physical workload between different subtasks under different topographic conditions. Similarly to the present study, both cardiovascular and biomechanical indicators did not reveal statistically significant differences between subtasks developed under horizontal and declive conditions.

In addition, Tereso et al..$^{15}$ showed a physical effort characterized as of moderate intensity at the most workers during tasks studied. This fact associated with work routines with long intermittent periods of effort and unfavorable weather conditions might favor the fatigue, impairment of muscle performance and eventual musculoskeletal disorders of these workers.

EMG has been an widely tool used to analyze muscular electrical activity, fatigue and also as practical importance to the low back pain ${ }^{16}$. The capture of the electromyographic signal exposes to diversified variables, such as: the RMS that illustrates how much the musculature is being requested for a certain activity; and the FM that checks the frequency of motor unit firing for muscle fiber ${ }^{17}$. Given the relationship between motor unit profile, muscle fiber types, and FM patterns, this variable has been used to monitor muscle fatigability ${ }^{16}$.

According to Rossi ${ }^{18}$, several physiological manifestations are found in individuals with low back pain, mainly in the muscles. The most common are decreased muscle activity, strength deficit, flexibility, endurance, and atrophy of some muscles. Melo et al. ${ }^{19}$, point out that individuals with low back pain show low resistance to fatigue of the trunk extensor muscles. Thus, evaluating and comparing the electromyographic activity of the trunk extensor muscles in individuals with and without low back pain is crucial for the search for a better understanding and thus consolidating EMG as a monitoring tool.

Electromyographic studies in coffee workers monitoring their physical efforts are scarce. In a study in Nicarágua, Bao et al. ${ }^{20}$ evaluated the electrical activity of upper trapezius, infraspinatus and lumbar paravertebral 
in order to compare a new bag to harvest in substitution of traditional basket. This experiment aimed to identify a more comfortable device for workers to improve working conditions in coffee harvesting in Nicaragua.

Up to date, we are unaware of any study using EMG comparing abdominal and paravertebral muscles in coffee harvesting activities. Given the originality of the study it is necessary to establish some speculations to better understand the results.

The posture commonly adopted by workers during coffee harvesting is with slight eccentric trunk flexion and antagonistic position of flexion and hip extension bilaterally, resulting in one foot in front of the other ${ }^{20}$ (Figure 5). This posture combined with the weight of the manual machine causes the body to be anteriorized, displacing the center of gravity ahead, thus increasing the recruitment of the paravertebral muscles, justifying its greater electrical activity when compared to the rectus abdominis.

In a completely different context ${ }^{21}$, anteriorization of the body as a function of shoe heel size in women during a short walk, projected the center of gravity ahead and showed that the paravertebral musculature was more requested in all postures adopted when compared to the rectus abdominis. The authors considered that to maintain the upright posture, there is a greater demand of the paravertebral musculature, thus explaining its greater electrical activity.

An association between low back pain complaints and high electrical activity of the paravertebral muscles when compared to low activity of the abdominal muscle has been reported ${ }^{22}$. Although experimental conditions do not allow full comparisons with the present study, Rangel, Bastos and Jorge ${ }^{22}$ observed that the posture of one foot in front of the other also generates an imbalance in the abdominal muscles, with a more requested abdomen when compared to the opposite side. Thus, the authors suggest the open base posture (parallel feet) as the most suitable for application of lumbar loads, because it offers greater lumbar stability. With this, we could indicate to coffee harvesting workers the use of the open base in an attempt to increase lumbar stability avoiding any musculoskeletal disorder.

According to the data analyzed, the abdominal muscles had a higher FM, when compared to the paravertebral muscles, i.e., the abdominal muscles presented motor units with depolarization frequencies compatible with higher fatigability muscle fibers when compared to the paravertebral muscles. This fact is related to the fiber typing

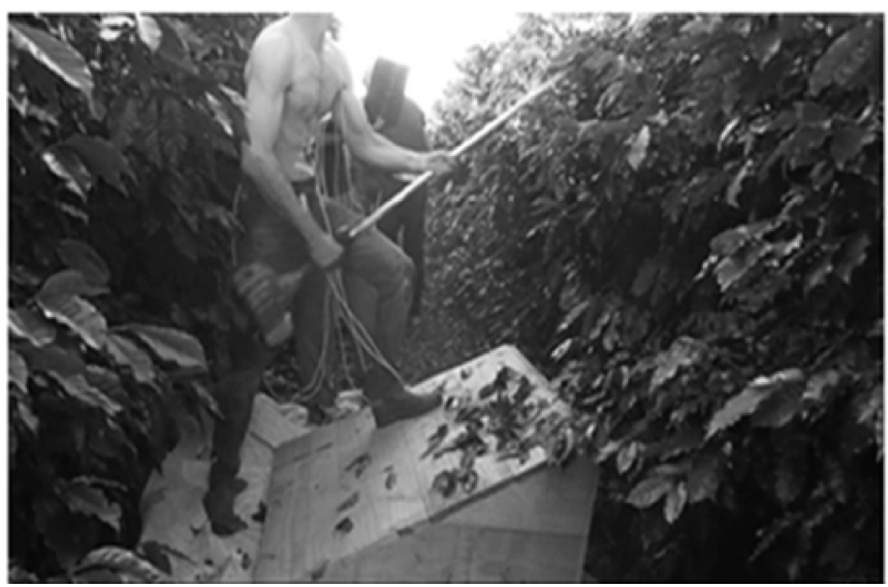

Figure 5. Position routinely adopted by workers during the coffee harvest. pattern of these two muscle groups. While antigravity muscles such as paravertebral muscles have a predominance of type I fibers ${ }^{23}$, in the abdominal musculature there is a predominance of type II fibers, explaining their higher FM compared to paravertebral fibers. According to Fioramonte ${ }^{24}$, the greater the number of type II motor units recruited, the greater the FM.

With this in mind, the position adopted by the workers and the working time could affect the stability of the lumbar spine and consequently lead to injuries. On average, the workers have a strenuous workday of 8 hours a day and the most used movements in coffee harvesting are trunk flexion and extension, mainly due to the handling of the manual machine in relation to the coffee tree. Thus, throughout the day a decrease in trunk muscle co-contraction could occur, affecting the stability of the lumbar spine.

The findings by Lee, Kang and Shin ${ }^{25}$ may explain in part the lower electrical activity of the abdominal muscles compared to the paravertebral muscles found in the present study. It was reported that deep static flexion for 10 minutes influenced the activation of antagonists of movement, decreasing its activation and consequently lumbar stability. Thus, analyzing the muscle activation, the agonist muscle of coffee harvesting activity is the paravertebral, and the antagonist the abdominal. With this, thinking about the working time, the movements performed and especially at the moment of the day that the collection was performed, in this case, in the middle of the working day, somehow may have influenced the lower electrical activity of the abdominal muscles in relation to the paravertebral, that is, the moment that the collection was performed both the abdominal and paravertebral muscles could already be previously fatigued.

Therefore, at the time of collection it is believed that both muscles were previously fatigued, with higher levels for the abdominal muscles, thus compromising their power activation and mainly reducing the process of co-contraction of the trunk muscles and consequently the lumbar stability, being able to result in case of long-term efforts in low back pain.

In practical terms it is necessary to consider that muscle strengthening programs for this population can be developed directed to the activation specificities presented here in order to favor a preventive action in the effort condition of the coffee culture worker.

It is suggested that in future studies workers may be evaluated before and after the workday, seeking to understand more clearly if the usual movements of the harvest may compromise the lumbar structures and cause low back pain.

\section{CONCLUSION}

We conclude that the footrest bases did not influence the RMS electromyographic activity nor the FM. However, it was found that the paravertebral muscles are more requested for the analyzed activity when compared to the abdominal muscles.

\section{ACKNOWLEDGMENTS}

The authors thank the financial support of the Research Support Foundation of the State of Minas Gerais (FAPEMIG - APQ-01917-14), and of the Federal Institute of Education, Science and Technology of South of Minas Gerais.

All authors declare no potential conflict of interest related to this article

AUTHORS' CONTRIBUTIONS: Each author made significant individual contributions to this manuscript.. EL, TOS and FFS: writing the article, revision and collection of the data, elaboration of the entire research project; WPH: statistical analysis, writing and revision of the article, elaborating of the entire research project; RAS: writing the article, revision, elaboration of the entire research project. All the authors revised and approved the final version of the manuscript. 


\section{REFERENCES}

1. Macedo RBM. Ergonomia aplicada na redução da dor lombar em ciclistas com o suporte da eletromiografia [dissertação]. Curitiba (PR): Universidade Tecnológica Federal do Paraná. 2014. [acesso em 2017 nov 16]:1-84. Disponível em: http://repositorio.utfpr.edu.br/jspui/handle/1/987.

2. Ulbricht L. Fatores de riscos associados à incidência de DORT entre ordenadores em Santa Catarina. [tese]. Florianópolis (SC): Universidade Federal de Santa Catarina. 2003 [acesso em 2017 out 27]; 1-237. Disponível em: https://repositorio.ufsc.br/bitstream/handle/123456789/86444/191726.pdf?sequence=>.

3. Queiroz PP, Schettino S, Minette LJ. Avaliação biomecânica da atividade de colheita semimecanizada de café em terrenos acidentados. In: Anais do V Congresso Brasileiro de Engenharia de Produção. 2015 [acesso 2018 fev 2];1-9. Ponta Grossa. Disponivel em: http://docplayer.com.br/32269338-Avaliacao-biomecanica-da-atividade-de-colheita-semimecanizada-de-cafe-em-terrenos-acidentados.html.

4. Briganó JU, Macedo CD. Análise da mobilidade lombar e influência da terapia manual e cinesioterapia na lombalgia. Semina: Ciências Biológicas e da Saúde 2005 [acesso em 2018 jan 15];10(2):75-82. Disponível em: http://www.uel.br/revistas/uel/index.php/seminabio/article/view/3555.

5. Lima FM, Quintiliano TR. A importância do fortalecimento do músculo transverso do abdômen no tratamento das lombalgias. [Trabalho de conclusão de curso]. Batatais (SP): Centro Universitário Claretiano. 2005 [acesso em 2018 jan 6];1-95 Disponível em: <http://www.pilateszone.com.br/wp-content/ uploads/2013/12/transverso-do-abdomem.pdf>

6. Alves JU, Souza AP, Minetti L, Gomes JM, Silva KR, Marçal MA, et al. Avaliação biomecânica de atividades de produção de mudas de Eucalyptos ssp. Rev Árvore. 2006 [acesso em 2018 jan 15];30(3):331-5. Disponível em: http://www.scielo.br/pdf/rarv/v30n3/a02v30n3.pdf.

7. Oliveira AG, Bakke HA, Alencar JF. Riscos biomecânicos posturais em trabalhadores de uma serraria. Fisioter Pesq. 2009 [acesso em 2017 ago 21]; 16(1):28-33. Disponível em: www.scielo.br/pdf/fp/v16n1/06.pdf.

8. Pereira JE, Pinto MC, Souza RA. Prevalência de lombalgias em transportadores de saco de café. Motriz. 2006 [acesso em 2017 mai 22];12(3): 229-238. Disponível em: http://www.periodicos.rc.biblioteca.unesp. br/index.php/motriz/article/view/414/355.

9. Tredicci $L V$, Ponte $A M . O A B C$ da eletromiografia de superfície e sua aplicação na ergonomia. In: Anais do $18^{\circ}$ Congresso Brasileiro De Ergonomia. Belo Horizonte. 2016 [acesso em 2017 out 27];1-6. Disponível em: http://workes.com.br/artigos1/18-congresso-ergonomia-25220.pdf.

10. Mesquita MC, Rezende JE, Carvalho JS, Fabri Júnior MA, Moraes NC, Dias PT, et al. Manual do café: colheita e preparo (Coffea arábica L.). Belo Horizonte: EMATER-MG, 2016. [acesso em 2018 out 27];1-56. Disponível em: http://www.sapc.embrapa.br/arquivos/consorcio/publicacoes_tecnicas/ livro_colheita_preparo.pdf.

11. Silva, AC. Detecção de possíveis áreas de mecanização da colheita do café em machado minas gerais. Ministério da ciência e tecnologia-Instituto nacional de pesquisas espaciais. São José dos Campos. 2013 [acesso em 2018 mai 5];1-20. Disponível em: http://wiki.dpi.inpe.br/lib/exe/fetch. php?media=ser300:trabalho_final_alexsandro_candido.pdf.

12. SENIAN. Eletromiografia de superfície para a avaliação não invasiva de músculos. 2017 [acesso em 2017 mai 5]. Disponível em: http://www.seniam.org/.

13. Silva GB. Caracterização da atividade elétrica dos músculos reto abdominal porção superior e inferior durante exercícios do método pilates. [Trabalho de Conclusão de Curso]. Muzambinho (MG): Instituto Federal de Educação Ciência e Tecnologia do Sul de Minas Gerais. 2013. [acesso em 2017 out 27];1-12. Disponível em: https://www.muz.ffsuldeminas.edu.br/attachments/2236_TCC\%20-\%20Licenciatura.pdf.

14. Xavier PL. Análise cinesiológica dos exercícios de rotação de tronco. [Trabalho de Conclusão de
Curso]. Porto Alegre (RS): Universidade Federal do Rio Grande do Sul. 2015. [acesso em 2017 out 27];1-37. Disponível em: https://lume.ufrgs.br/bitstream/handle/10183/133055/000983905. pdf? sequence $=1$ \&isAllowed $=\mathrm{y}$.

15. Tereso MJ, Abrahão RF, Barbosa MA, Lima RR, Chih LY. Aspectos biomecânicos e fisiológicos da carga de trabalho na cafeicultura do sul de Minas Gerais. Revista Ação Ergonômica. 2015 [acesso em 2019 ago 6];10(1): 99-10. Disponível em: http://www.abergo.org.br/revista/index.php/ae/ article/view/337/242.

16. Kawano MM, Souza RB, Oliveira BI, Menacho MO, Cardoso AP, Nakamura FY, et al. Comparação da fadiga eletromiográfica dos músculos paraespinhais e da cinemática angular da coluna entre indivíduos com e sem dor lombar. Rev Bras Med Esporte. 2008 [acesso em 2017 dez 21];14(3):209-14. Disponível em: http://www.scielo.br/pdf/rbme/v14n3/a10v14n3.pdf.

17. Noda DK, Marchetti PH, Vilela Junior GB. A Eletromiografia de superfície em estudos relativos à produção de força. Revista CPAQV-Centro de Pesquisas Avançadas em Qualidade de Vida. 2014 [acesso em 2017 dez 21];6(3):1-24. Disponível em: https://www.researchgate.net/publication/268870576_artigo_de_revisao_a_eletromiografia_de_superficie_em_estudos_relativos_a_producao_de_forca_surface_electromyography_in_studies_on_the_force_production_2014.

18. Rossi TN. Efeitos do exercício físico sobre a lombalgia. Rev Bras Presc Fisiol Exerc. 2011 [acesso em 2017 nov 25];5(26):163-9. Disponível em: http://www.rbpfex.com.br/index.php/rbpfex/article/viewFile/316/316.

19. Melo MO, Torre M, Dutra LA, Pressi AM, Castro FA, Loss JF, et al. Avaliação da dor lombar através da eletromiografia. In: Anais do XII Congresso Brasileiro de Biomecânica. 2007 [acesso em 2018 jan 22];165-70. São Paulo. Disponível em: http://www.ufrgs.br/biomec/articles\%202/12\%20(XII)\%20CBB/Melo\%20-\%20Dor\%20Lom\%20e\%20EMG.pdf.

20. Bao S, Silverstein B, Stewart K. Evaluation of an ergonomics intervention among Nicaraguan coffee harvesting workers. Ergonomics. 2013; [acesso em 2019 ago 6];56(2):166-181. Disponivel em: https:// www.tandfonline.com/doi/abs/10.1080/00140139.2012.760753.

21. França AF, Ávila KF, Bonifácio DN, Martins FL, Barbosa MC, Barbosa AW. Influência da altura do salto do sapato na atividade elétrica os músculos paravertebrais lombares e reto abdominal superiores. Ter Man. 2012 [2017 out 8]; 10(50):476-479. Disponível em: https://www.researchgate.net/profile/Alexandre_Barbosa4/ publication/259891121_Influence_of_high_heels_in_the_electrical_activity_of_lumbar_paravertebral_and_upp r_rectus_abdominis/links/546099d00cf2c1a63bfe2224/Influence-of-high-heels-in-theelectrical-activity-of-lumbar-paravertebral-and-upper-rectus-abdominis.pdf.

22. Rangel FR, Bastos CV, Jorge SF. Análise eletromiográfica dos músculos paravertebrais lombares e abdominais durante a execução do exercício tipo rosca direta de bíceps em diferentes posturas. Rev Perspectiva (online). 2010 [acesso em 2017 mai 22];4(16):156-162. Disponível em: http://www.seer. perspectivasonline.com.br/index. php/revista_antiga/article/view/472/388.

23. Mannion AF. Fibre type characteristics and function of the human paraspinal muscles: normal values and changes in association with low back pain. J Electromyogr kinesiol. 1999;9(6):363-77.

24. Fioramonte I. Estudo do sinal eletromiográfico em exercícios isométricos em diferentes velocidades de contração [dissertação]. Presidente Prudente (SP): Universidade Estadual Paulista. 2011 [acesso em 2018 dez 9];1-76. Disponível em: https://repositorio.unesp.br/bitstream/handle/11449/87296/ fioramonte_isk_me_prud.pdf?sequence=1\&isAllowed=y.

25. Lee N, Kang H, Shin G. Use of antagonista muscle EMG in the assessment of neuromuscular health of the low back. J Physiol Anthropol. 2015 [acesso em 2018 jan 22];34(18):1-6. Disponível em: https://www. ncbi.nlm.nih.gov/pubmed/25906775. 